\title{
Leveraging on the Urban Economy to Promote the Growth of Women-Owned Small Businesses in Bangladesh
}

\author{
Nusrat Hafiz ${ }^{1 *}$ Ahmad Shaharudin Abdul Latiff ${ }^{2}$ \& Sazali Abd Wahab ${ }^{3}$ \\ ${ }^{1}$ PhD Candidate, Putra Business School, UPM, Selangor, Malaysia; and Lecturer, BRAC Business School, BRAC University, \\ Bangladesh \\ ${ }^{2}$ Senior Lecturer, Putra Business School, UPM, Selangor, Malaysia \\ ${ }^{3}$ Professor, Putra Business School, UPM, Selangor, Malaysia \\ *Corresponding author: nusrat.phd mgt18@grad.putrabs.edu.my
}

DOI:https://doi.org/10.38157/business-perspective-review.v3i1.234

Citation: Hafiz, N., Latiff, A.H.A. \& Wahab, A.A., (2021). Leveraging on the Urban Economy to Promote the Growth of Women-Owned Small Businesses in Bangladesh. Business Perspective Review 3(1), 15-23. DOI: https://doi.org/10.38157/business-perspective-review.v3i1.234

\section{Research Article}

\begin{abstract}
Purpose: The contribution of small businesses to a country's economic growth is vital. It makes sense to accentuate the small businesses by emphasizing the neglected segments. The present study aims to explore the women-owned small businesses (WOSB) and their various problems. The study also examines if the city-based features of the urban economy can be favorable to promote the growth of WOSB.

Methods: The concept paper conducts secondary research by selecting sample literature on WOSB of Bangladesh from the manufacturing, and trading sectors. The selection and classification of extant literature were conducted by emphasizing problems faced by WOSB, and the city-based amenities of developing countries. The extracted information is analyzed by categorizing and interpreting relevant issues to create a base-model of venture-growth.

Results: Based on the literature review, a growth-framework is formulated that reflects the issues faced by WOSB categorized as financial illiteracy, inadequate human capital, insufficient social capital, and business environmental hiccups. Also, the substandard growth of WOSB is envisaged in the model if the problems are not addressed timely. The study also discovers that the urban economy could be leveraged to make these issues less coercing for the women owners.

Implications: The paper creates a nexus with the WOSB and the privileges of urban platforms to ensure better growth of the firms.

Originality: As far as authors could determine, the aimed research-domain was mostly covered from the perspectives of developed countries, rarely covered in the context of developing countries, and almost absent in Bangladesh. This paper attempts to fulfill that gap.
\end{abstract}

Keywords: Small business, women-owned small business, urban economy, growth, developing country, city-based features. 


\section{Introduction}

The integral agents of innovation in an economy are the women entrepreneurs, who contribute largely to a country's industrial and economic growth. While more than 60 percent of women operate established businesses worldwide (Babson College, 2019), they often choose entrepreneurship as an alternative to unemployment. Compared to their male-counterparts, end up making lower turnover in the developing countries (Naudé, 2018). Bangladesh is no exception, which is subject to intricate socio-economic hitches, dubious institutional support, volatile business environments, and various macro-issues sourcing from the instability of jobs, businesses, and other economic growth parameters both on general and gender-specific levels.

The women workforce consists of almost half of the entire workforce, who contribute to some 34 percent of the Gross Domestic Product (GDP) of Bangladesh (Asian Age, 2017). Out of these, the majority of women entrepreneurs own small-scale businesses. Despite their contribution, the owners of women-owned small businesses (WOSB) face adversity in the business environment, associated with resource-constraints, procedural bureaucracies, and corruption (Hasan, 2020). These results in their poor performance (Jennings \& Brush, 2013), low profits (The Financial Express, 2019), poor resilience, and low growth-orientation (Alsos, Isaksen, \& Ljunggren, 2006). The women owners deserve special attention to ensure the growth and survival of their ventures. The concept paper stresses the problems associated with the WOSB and connects the features of the urban economy as an approach to endorse their venture-growth.

\section{Literature Review on Women-owned small businesses (WOSB)}

In Bangladesh, though most women entrepreneurs own small-scale businesses; to be eligible as official women entrepreneurs, they need to own an entire business as proprietor or at least 51 percent of a partnership business that is registered with the office of Register of Joint Stock Companies (RJSC), according to Industrial Policy 2016 (The Financial Express, 2020).

\subsection{Issues exposed by WOSB}

The generic small businesses are predisposed to insufficient resources, low managerial and entrepreneurial capabilities, brittle structures, limited technological and market know-how, etc. (Banwo, Du, \& Onokala, 2017)._Due to their over-dependence on short-term cash flow, the average small firms are more susceptible to the economic crisis due to pandemic (Becker Friedman Institute, 2020); which, unfortunately, have faced up to an 80 percent drop in sales turnover (Marie-France Derderian, 2020) regardless of firm owners' gender (Lalon, 2020). Without addressing the problems correctly and promptly, the growth and survival of the WOSB will become a key challenge for a developing and pandemic-ridden country (The Financial Express, 2019). The key problems that depress the performance and growth of WOSB are exposed to numerous issues.

For instance, women's lack of financial capital (Rachmawati, Shukri, Azam, \& Khatibi, 2019) has been among the most common factors of poor firm growth, which is largely contributed by their insufficient financial literacy (Schneider, 2017). This financial illiteracy often results in 
transformational disadvantages such as incapability in decision-making (Fatoki, 2014); reduced control over financial resources; mismanaging and misallocating of funds, and adopting improper investment vehicles (Agyei \& Nsiah, 2018), which are essential elements for business growth among the small firms (Maziriri, Mapuranga, \& Madinga, 2018). Women entrepreneurs also face business environmental constraints (Kain \& Sharma, 2013) in terms of their human capital development essential for business growth. They are often subject to lower prospects in availing higher-education and relevant technical and vocational education and training (TVET) (EDIG, 2018) and access to training (United Nations, 2017); less opportunity to career advancement, substandard freedom of expression, and freedom of mobility (The Daily Star, 2017).

The poor social and support networking facility (The Daily Star, 2017) is a common phenomenon in developing country-perspective, which prevents the women entrepreneurs to have proper market access (Ahmed, Hossain, \& Hossain, 2018). The limited options available for them to exchange ideas with mentors and peers fail to motivate them towards firm growth (Hasan, 2020). Overall, women are susceptible to diverse business factors including unfair market practices, bureaucracy, nepotism, strikes, siege, blockades, unsafe transports, and autocratic attitudes by financial and political organizations. Absence of job security, personal safety at workplaces, and one-stop operating platforms (Islam, Jantan, Hunt, Rahman, \& Abdullah, 2019) curtail their operational efficiency.

\subsection{Probable Consequences of prevailing issues}

Under the present context, low-growth orientation, managerial deficiency (Kain \& Sharma, 2013), and information-gap (United Nations, 2017) in the WOSB are prominent. The issues can be broadly be categorized as financial illiteracy, shortage of human capital, inadequate social capital, and business environmental hiccups. If the addressed issues remain untreated, the WOSB are likely to experience poor growth of their ventures. A persistent substandard growth may lead to the closure of many of their firms. Among the other effects, the distressed skill-level and increased social crimes could be inevitable. Hence, the business-constraints exposed by the women owners of small businesses would have chain-effects. At the primary level, there may be degraded performance and growth of their business and at the tertiary level, there may be depressed living standards of the entire community.

Figure 1 summarizes the findings of extant literature and portrays the issues and their consequence of WOSB in terms of growth. Such a complex interplay of diverse factors is going to limit the entrepreneurial potential of women in developing economies. The operational difficulties caused by the issues could hinder the competitive spirit among the women entrepreneurs, owners, and managers. In due course, the country's potential to achieve fullcapacity economic growth is predicted to be challenged as an aftermath of the low growth of WOSB. 


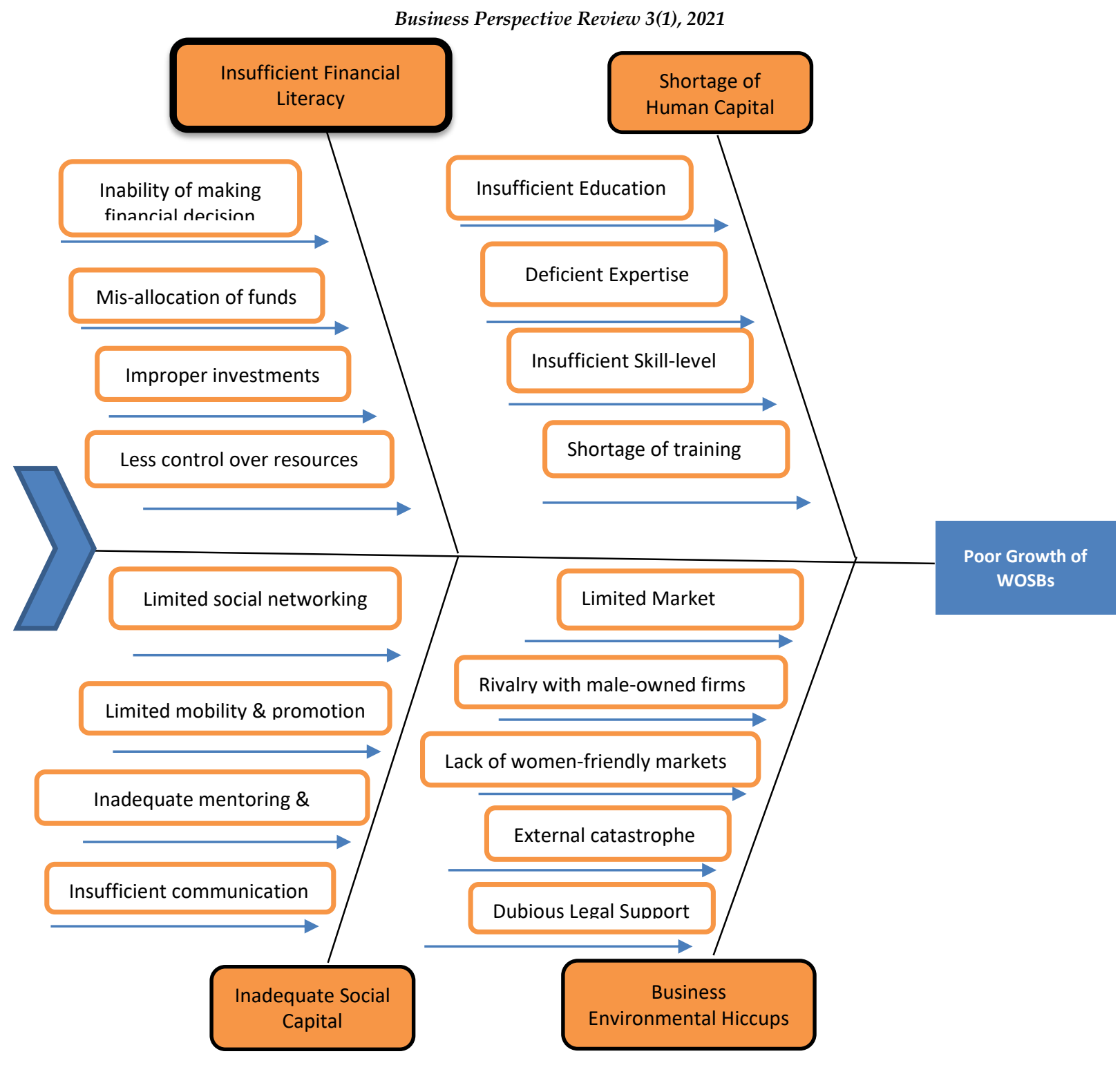

Fig 1. Fishbone model of issues and consequence of WOSB

\subsection{Role of Urban Economy to promote WOSB growth}

With enhanced accessibility of financial amenities, "entrepreneurship capital" (startup-friendly social networks), and professional networking, the urban cities are turning to be melting pots of higher productivity and income for businesses (Hasan, 2020). The urban economy also promotes the mobility of resources, production factors, and intellectual ability (Glaeser, Stuart, \& William, 2009), which is conducive to innovation, commercialization, and business growth. The city-based educational, financial, and regulatory institutions were also found to be promising for the entrepreneurs. Various high-end educational institutes and training establishments, public transportation, and legal administration are available in the cities. The greater business growth would lead to higher urban economic growth too, which in turn, would lead to greater knowledge spillovers and the commercialization of innovative ideas (Hasan, 2020). Given this, small business 
growth may be considered as both the cause and effect of market creation and economic growth at an urban platform.

In Bangladesh, the urban area consists of cities, megacities, small towns, Cantonment, and municipality areas known as 'Paurashava' (Bangladesh Bureau of Statistics, 2015). The women workforce operating in urban platforms have raised from 23.9 percent to 36.3 percent between 2000 and 2017, according to The Centre for Development and Employment Research (CDER) and the Friedrich-Ebert-Stiftung (FES) reports (The Daily Star, 2019). Their growth is predicted to be 82 percent over the next decade and they are expected to contribute to some 1.8 percent to Bangladesh's GDP (The Daily Star, 2015).

The city-based women entrepreneurs have increasingly been evolving. They have been extensively participating in diverse areas including boutiques, interior designing, jewelrymaking, catering services, poultry farming, beauty salons and spas, schools, diagnostic centers, online businesses, and export-oriented ventures (Sultana, 2012). They have been progressively gaining an edge over their rural counterparts. With greater managerial skills, education, and internet-expertise (Tabassum, 2019); ingenuity, resilience, and the capability of taking financial and administrative responsibilities; along with government and non-government agency-level “institutional and policy-driven" support (Sultana, 2012), they may become a crucial catalyst of the 'smart cities' soon (Asian Age, 2017).

\section{Objective and Methodology}

Based on the literature, urbanization is expected to instigate women-owned establishments in small firms. Nevertheless, literature regarding the proper direction and degree of growth of women-owned ventures has remained scanty. As far as the authors could determine, no previous study was conducted on the growth of WOSB of Bangladesh. Hence, the present study aims to fill the void of entrepreneurial literature and advance the knowledge by connecting the spatial and gender-based perspectives of entrepreneurship. Before determining whether the urban economy is favorable for WOSBs' growth or not, exploring the problems or issues faced by WOSB should be the first step. Hence, the key objectives of the study are:

i. to explore the prevailing problems and issues faced by WOSB of Bangladesh and likely consequences,

ii. to analyze the entrepreneurial scope from spatial context and determine if the city-based features can create a positive business environment for WOSB and

iii. to propose mitigants to the issues leading to poor growth WOSB, by collaborating city based-features.

This concept paper uses exploratory research design to expound on the area of study. The study reviews empirical literature of women's entrepreneurship and city-based facilities from business contexts. The authors collected information from published articles and book chapters from databases including ProQuest, and Google Scholar. The data sources also include website articles, blogs, seminars, dialogues, and news portals. The time horizon of the published materials was 2013 to 2020. 
While searching the relevant literature, six key terms were inserted in the search engine, such as 'urban economy', 'venture growth', 'small business', 'Bangladesh', 'developing countries', and 'women-owned SME'. Following the data collection methods advised by (Flynn, Sakakibara, Schroeder, Bates, \& Flynn, 1990), the literature was selected to build a theoretical foundation; and then was classified and screened further based on specific research objectives of the study. The literature was classified into two phases. While first-phase literature emphasized the problems or issues faced by women-owners, the second phase literature focused on the city-based amenities of developing countries. The extracted information was interpreted to create a framework explaining the status of WOSB-growth.

The framework produced in the concept paper is expected to be used as a base-model to derive an appropriate variable-set for empirical research-work at Doctoral-level. The factors of issues derived from the present study are expected to lead to a detailed analysis of the variables of firmgrowth, using quantitative analysis.

\section{Discussion}

Urbanization has turned out to be an influential buzz-word in the process of globalization. The city-population worldwide is estimated to be doubled by the United Nations by 2030 from 30 percent in the 1950s (Kahn, 2009). The spectacle not only took over the developed and developing countries, but it also became a crucial benefactor of economic and business growth. With infrastructural and supply chain opportunities in a dense network, gain support from the government, financial institutions, agencies, incubation platforms, and commercial ports (Banwo, Du, \& Onokala, 2017), the city-based 'location-economy' can be inferred to augment the scope of business growth.

Besides that, the cities are characterized by an advanced heterogeneous bundle of skill-capital, the immediacy of factors and products markets locations, smoother marketing due to technology, a comparatively greater influence on policy-making regimes, improved transportation and communication may help the WOSB to save costs and thereby raise profits to generate financial growth. The urban facilities also help reduce the rigidity-level of WOSB and transform those to be better respondents in the dynamic economy.

The cities may also be contrary to business growth by imposing pressure on local resources that could lead to a bottleneck of resources and increase property prices and rents and trigger fierce business competition. Also, messy urbanization could follow the increased emission of per-capita carbon print and environmental pollution (World Bank, 2015). These may deter net earnings and financial growth of small firms. Nevertheless, the urbanized amenities offer the resourcedeprived women owners a unique set of opportunities, which is absent in the rural platform. As a more lenient and change-agent, the urban platform offers greater socio-economic acceptance for the WOSB. With the clustering of the small firms (Boisot \& Child, 1999), the urban economy triggers innovation, ensures better infrastructure-facilities (Banwo, Du, \& Onokala, 2017), and offers credible location-specific advantages favorable for the WOSB.

\section{Proposed Initiatives}


Given the diverse problems of WOSB, leveraging on the location-specific advantage of the economic cluster or "location economy" could be a credible approach. Given the present context, in Table 1, the study proposes city-based measures as the mitigants to the key problems of WOSB and to promote the growth of the WOSB.

Table 1. Proposed mitigants of WOSB issues

\begin{tabular}{|ll|}
\hline Key issues of WOSB & \multicolumn{1}{c|}{ Proposed Mitigants } \\
\hline $\begin{array}{l}\text { Financial Literacy } \\
\text { Bnadequate } \quad \text { Human } \\
\text { Capital }\end{array}$ & $\begin{array}{l}\text { 'target-based' and 'collateral-free' loans, app-based financial services (Hafiz \& } \\
\text { Latiff, 2020), and one-stop digital business platforms for women entrepreneurs. } \\
\text { based women-friendly technical and vocational training programs through their } \\
\text { respective club or forums (Hafiz \& Latiff, 2020). }\end{array}$ \\
\hline $\begin{array}{l}\text { Insufficient } \\
\text { Capital }\end{array}$ & $\begin{array}{l}\text { The dedicated agencies and incubation platforms may introduce city-centric } \\
\text { entrepreneurial concepts, including entrepreneurship capital (Hasan, 2020), } \\
\text { regional knowledge-based entrepreneurial activities (Audretsch, Werner, \& } \\
\text { Max, 2008), and promote women-based communities. }\end{array}$ \\
\hline $\begin{array}{l}\text { Business } \\
\text { Environmental } \\
\text { Hiccups }\end{array}$ & $\begin{array}{l}\text { Policymakers should ratify policies to protect the interest of WOSB (The } \\
\text { Financial Express, 2019) by minimizing the level of corruption, bureaucracy and } \\
\text { allowing greater resource-accessibility. }\end{array}$ \\
\hline
\end{tabular}

\section{Conclusion}

Given the context of problems faced by WOSB in Bangladesh, the inclusion of urban economies has been considered to be a timely approach. The cluster economy's amenities can offset the resource-limitations, bureaucracy, and corruption with the benefits offered by educational, financial, and regulatory institutions. To stay relevant with the wave of globalization and urban platform, ensuring the growth of WOSBs through various agencies, financial institutions, universities, and incubation platforms is imperative. Nevertheless, mitigating the problems faced by WOSB may require a multi-pronged approach, which again is subject to resource-constraints and priority from developing country's perspectives. Empirical research may be conducted in detail by the researchers to address the problems and examine the growth-perspective of the WOSB of developing countries.

Authors' Contributions: Dr. Ahmad conceived the idea, Ms. Nusrat collected and analyzed data; Dr. Sazali suggested for improvement; Ms. Nusrat wrote the paper.

Conflict of Interest: The authors declare no conflict of interest.

\section{REFERENCES}

Agyei, S., \& Nsiah, C. (2018). Culture, Financial Literacy and SME performance in Ghana. Cogent Economics \& Finance, $6(1)$. 
Business Perspective Review 3(1), 2021

Ahmed, N., Hossain, M., \& Hossain, I. (2018). Women Entrepreneurs in SMEs: Bangladesh Perspective. Dhaka: BIDS Almanac. Retrieved from https://bids.org.bd/uploads/events/almanac2018/TS-2_P-3.pdf

Alsos, G., Isaksen, E., \& Ljunggren, E. (2006). New Venture Financing and Subsequent Business Growth in Men- and Women-led Businesses. Entrepreneurship Theory and Practice, 30(5), 667-686.

Asian Age. (2017, September 21). Women's contribution to GDP growth 34\%: PM. Retrieved from https://dailyasianage.com/: https://dailyasianage.com/news/86916/womens-contribution-to-gdp-growth-34$\mathrm{pm}$

Audretsch, D. B., Werner, B., \& Max, K. (2008). Entrepreneurship Capital and its impact on Knowledge Diffusion and Economic Performance. Journal of Business Venturing, 23(6), 687-98. doi:https://doi.org/10.1016/j.jbusvent.2008.01.006

Babson College. (2019, November 18). More Than 250M Women Worldwide Are Entrepreneurs, According to the Global Entrepreneurship Monitor Women's Report from Babson College and Smith College. Retrieved from PR Newswire: https://www.prnewswire.com/news-releases/more-than-250m-women-worldwide-are-entrepreneursaccording-to-the-global-entrepreneurship-monitor-womens-report-from-babson-college-and-smith-college300960196.html

Bangladesh Bureau of Statistics. (2015). Population Monograph of Bangladesh: Age-Sex Composition of Bangladesh Population. Dhaka: Dhaka: Government of the People's Republic of Bangladesh.

Banwo, A., Du, J., \& Onokala, U. (2017). The determinants of location-specific choice: small and medium-sized enterprises in developing countries. Journal of Global Entrepreneurship Research, 7(1).

Becker Friedman Institute. (2020). How Are Small Businesses Adjusting to COVID-19? Early Evidence from a Survey. Retrieved from Becker Friedman Institute: https://bfi.uchicago.edu/working-paper/how-are-smallbusinesses-adjusting-to-covid-19-early-evidence-from-a-survey/

Boisot, M., \& Child, J. (1999). Organizations as Adaptive Systems in Complex Environments: The Case of China. Organization Science, 10(3), 237-252.

EDIG. (2018). Female Employment Stagnation in Bangladesh. Retrieved from EDIG: https://asiafoundation.org/wpcontent/uploads/2018/12/EDIG-Female-employment-stagnation-in-Bangladesh_report.pdf

Fatoki, O. (2014). The Financial Literacy of Micro-Entrepreneurs in South Africa. Journal of Social Sciences, 40(2), 1518.

Flynn, B., Sakakibara, S., Schroeder, R., Bates, K., \& Flynn, E. (1990). Empirical Research Methods in Operations Management. Journal of Operations Management, 9(2), 250-284.

Glaeser, E., Stuart, R., \& William, S. (2009). Urban Economics and Entrepreneurship. Journal of Urban Economics, 67, 1-14. doi:https://doi.org/10.3386/w15536

Hafiz, N., \& Latiff, A. A. (2020). Entrepreneurship as a Sustainable Solution for the Female Graduates in the SME sector of Bangladesh. Journal of Business and Social Review in Emerging Economies, 6(2), 483-92. doi:https://doi.org/10.26710/jbsee.v6i2.1010

Hasan, M. (2020). Female Entrepreneurship: Do Urban Centers Ease Out the Challenge? In M. Iftikhar, J. Justice, \& D. Audretsch, Urban Studies and Entrepreneurship (pp. 163-178). Springer International Publishing.

Islam, M., Jantan, A., Hunt, A., Rahman, M., \& Abdullah, M. (2019). Exploration of Barriers faced by female graduate entrepreneurs in Bangladesh. Entrepreneurship \& Sustainability Issues, 7(2), 1000-14.

Jennings, J., \& Brush, C. (2013). Research on Women Entrepreneurs: Challenges to (and from) the Broader Entrepreneurship Literature? The Academy of Management Annals, 7(1), 663-715.

Kahn, M. E. (2009). Urban growth and climate change. Annual Review of Resource Economics, 1(1), 333-350. doi:https://doi.org/10.1146/annurev.resource.050708.144249

Kain, P., \& Sharma, M. (2013). Women Entrepreneurship Education Need for Today. Journal of Management Sciences and Technology, 1(1), 43-53.

Lalon, R. (2020). COVID-19 vs Bangladesh: Is It Possible to Recover the Impending Economic Distress Amid This Pandemic? SSRN Electronic Journal.

Marie-France Derderian. (2020). What is the Impact of COVID-19 on Entrepreneurship? Retrieved from Marie-France Derderian: https://www.hospitalitynet.org/opinion/4098262.html 
Maziriri, E., Mapuranga, M., \& Madinga, N. (2018). Self-service banking and financial literacy as prognosticators of business performance among rural small and medium-sized enterprises in Zimbabwe. The Southern African Journal of Entrepreneurship and Small Business Management, 10(1), 1-10.

Naudé, W. (2018). Urbanization and Entrepreneurship in Development: Like a Horse and Carriage? In M. Dastbaz, W. Naudé, \& J. Manoochehri, Smart Futures, Challenges of Urbanisation, and Social Sustainability (pp. 29-47). Cham: Springer. doi:https://doi.org/10.1007/978-3-319-74549-7_3

Rachmawati, D., Shukri, S., Azam, S., \& Khatibi, A. (2019). Factors influencing customers' purchase decision of residential property in Selangor, Malaysia. Management Science Letters, 9(9), 1241-8.

Schneider, K. (2017). Promoting the Entrepreneurial Success of Women Entrepreneurs Through Education and Training. Science Journal of Education, 5(2), 50-9.

Sultana, I. (2012). The Emerging SME Women Entrepreneurs in Dhaka City. Journal of Business Studies, 33(1), 15-34.

Tabassum, T. (2019). Facebook-based Women Entrepreneurship in Bangladesh: Opportunities and Challenges. Bangladesh Journal of Public Administration (BJPA), 26(2), 79-96. doi:https://doi.org/10.36609/bjpa.v26i2.22

The Daily Star. (2015, October 11). Women workforce growing fast. Retrieved from The Daily Star: https://www.thedailystar.net/frontpage/women-workforce-growing-fast-155149

The Daily Star. (2017). Challenges for women entrepreneurs. Retrieved from The Daily Star: https://www.thedailystar.net/education-employment/challenges-women-entrepreneurs-1366573

The Daily Star. (2019, September 01). Women Employment Falling in Urban Areas. Retrieved from The Daily Star: https://www.thedailystar.net/business/bangladesh-female-employment-falling-in-urban-areas-1793668

The Financial Express. (2019, March 21). Female Entrepreneurship in Bangladesh. Retrieved from The Financial Express: https://hefinancialexpress.com.bd/views/female-entrepreneurship-in-bangladesh-1553181544

The Financial Express. (2020, September 23). Defining woman entrepreneurship. Retrieved from The Financial Express: https://www.thefinancialexpress.com.bd/views/reviews/defining-woman-entrepreneurship-1600615442

United Nations. (2017). Fostering Women's Entrepreneurship in ASEAN- UN ESCAP. Retrieved from United Nations: https://www.unescap.org/sites/default/files/ESCAP_Fostering_Womens_Entrepreneurship_Full.pdf

World Bank. (2015). Leveraging Urbanization in South Asia: Managing Spatial Transformation for Prosperity and Livability. World Bank. Retrieved from https://doi.org/10.1596/978-1-4648-0662-9 